\title{
Formation of the resource concept in Japan: pre-war and post-war efforts in knowledge integration
}

\author{
Jin Sato
}

Received: 27 December 2006/Accepted: 18 May 2007/Published online: 27 July 2007

(C) Integrated Research System for Sustainability Science and Springer 2007

\begin{abstract}
The objective of this paper is to trace the evolution of the resource concept in modern Japan by highlighting key individuals who played major roles in communicating this idea to a wider audience during its formation and development between the 1910s and 1950s. Special attention will be paid to the effect of different historical contexts on interpretations of the term "resource". The paper reveals how the integration of knowledge indispensable for achieving sustainability occurs. The orientation of resource policy was drastically different before and after World War II. In the pre-war period, the military government used the resource concept to create a comprehensive inventory of the nation's military forces, and "resource" was thus a convenient term to neutralize the aggressive connotations of top-down military mobilization. After the turn to democratic principles in 1945, "resource" suddenly acquired a symbolic meaning as a means to serve the people. Despite these contrasts, however, pre and post-war resource concepts share a commonality in that the government acted as the centralizing force, providing a platform to integrate disparate knowl-
\end{abstract}

An earlier version of this paper was presented at the International Workshop on Crossing Borders in Sustainability Development held at The University of Tokyo on February 4, 2006. I would like to thank the anonymous reviewers for their constructive comments. This work was supported by MEXT through Special Coordination Funds for Promoting Science and Technology, as a part of the flagship project for "Development of the Philosophy of Sustainability Science" undertaken by the University of Tokyo.

J. Sato $(\bowtie)$

Department of International Studies,

Graduate School of Frontier Sciences,

The University of Tokyo,

5-1-5 Kashiwanoha, Kashiwa-shi, Chiba, Japan

e-mail: satoj@k.u-tokyo.ac.jp edge under the resource concept. At a time when society itself is more prone to fragmentation, the resource concept, which played a significant role in unification in the past, should be re-examined. The history of the concept in Japan, particularly during the pre and post-war period up until the 1950 s, contains a wealth of insights as to how this can be achieved.

Keywords Resource concept - Resource council · Japan $\cdot$ Knowledge integration

\section{Introduction}

This paper has two main objectives. The first is to trace the evolution of the resource concept in modern Japan by highlighting key individuals who played major roles in communicating this idea to a wider audience during its formation and development between the 1910s and 1950s. ${ }^{1}$ Unlike Western countries where "resource" has been in use since the late nineteenth century, the Japanese equivalent shigen has been used publicly only since the 1920s. This paper will pay special attention to the effect of different historical contexts on interpretations of the term "resource". The second objective is reveal how the integration of knowledge that is indispensable for achieving sustainability occurs. There were strong forces and mechanisms that integrated resource policies up to the 1950s; however, these legacies have been almost completely for-

\footnotetext{
${ }^{1}$ Shigen sporadically appears in newspapers from ca 1904, and is used almost interchangeably with "financial resources" (zaigen). It was in the 1910s that shigen began to be used in the present sense of "resource".
} 
gotten, especially since the rise of environmental movements in the 1970s.

As Japan has long portrayed itself as a "resource-poor" nation, it is interesting to examine the emergence and stabilization of the resource concept with its associated subtexts. In the current era when knowledge specialization is encouraged, "resource" is an appropriate concept to revisit because it facilitates a unified understanding of the various components of natural systems (water, land, forests, minerals, etc.) as an interconnected entity. Furthermore, the act of defining a resource from other potentially beneficial natural phenomena provides insight into the state of human relationships with the natural world. The resource concept thus opens up a common frame of reference for both natural and social scientists.

Public interest in the state of natural resources was sustained until the two "oil shocks" of the 1970s; since then, it has gradually waned or else been neglected by the media and the government. As the gross domestic product (GDP) of Japan became the second largest in the world in the late 1960s, behind the United States, the supply of natural resources rapidly shifted towards importation rather than domestic production. ${ }^{2}$ Although these changes may provide reasons to downgrade the importance of the resource concept, the consistent increase in total resource consumption ensures that "resources" will always be a topic of vital importance for Japan. ${ }^{3}$

There are three specific reasons why an investigation into the resource concept is meaningful. First, knowledge of the formative and diffusive processes of an important concept is inherently valuable from a social science viewpoint. Such concepts may also induce policymakers to favor certain ways of defining various "problems" while validating particular actions as relevant for solving them. In other words, concepts influence perceptions of current issues facing modern societies. However, such concepts are never independent from the wider context in which they operate. Since the invention of the resource concept in Japan almost a century ago, public attention to resource issues has fluctuated substantially, both quantitatively (in terms of published documents) and qualitatively (in terms of the context in which the word "resource" is used). These changes reflect the contextual nature of the concept, and

\footnotetext{
${ }^{2}$ Percentage share of domestic production of coal, for example, decreased from $76 \%$ in 1965 to $20 \%$ in 1980 (Energy white paper 2006, http://www.enecho.meti.go.jp/topics/hakusho/2006EnergyHTML/ html/i1240000.html).

${ }^{3}$ Japan currently imports almost $100 \%$ of its oil, $97 \%$ of its natural gas, $100 \%$ of its copper, $92 \%$ of its zinc, and $80 \%$ of its timber. Although reliance on oil for energy production has gradually diminished because of the diversification of energy sources, oil still accounts for $50 \%$ of total energy consumption (from the JOGMEC home page at http://www.jogmec.go.jp/english/index.html).
}

thus must be explained by the surrounding social, economic, and political circumstances.

The second reason for this investigation is to help fill a gap that exists in the current environmental studies in Japan that emerged in the 1970s, including environmental sociology, economics, policy, and law. Various modes of academic inquiry regarding natural resources and the environment were formulated primarily as a response to increasingly severe pollution problems (kogai) that occurred as a consequence of rapid industrialization in the 1950s and 1960s, and little attention was paid to the choice of resources that produced those side effects. Although natural and social sciences related to agriculture, forestry, and fisheries addressed resource concepts, these were still regarded as separate fields of investigation; thus little interdisciplinary communication occurred.

The third reason for this investigation is that there is a wealth of ideas in history yet to be utilized on how to integrate knowledge for the purpose of problem solving. Re-examining the advantages of the interdisciplinary approach used previously in resource studies will shed light on the present effort to integrate various sciences in solving the problems of sustainability and environmental damage. Since the idea of a "resource" by definition lies between the realms of natural and social science, resource policies also require the integration of both types of knowledge. In Japan, serious attempts at "integration" occurred in the wake of World War II, as the loss of overseas colonies forced the country to focus almost entirely on the domestic procurement of resources to sustain its population.

\section{Shifting attention}

\section{Publication trends}

Awareness of the resource concept can be most easily quantified from increases in the number of resource-related publications. Figure 1 shows the number of resourcerelated works published since the 1920s, when the term "resource" (shigen) was first introduced to a wider audience. The data were collected from the library archives of The University of Tokyo, one of the largest collections in Japan, particularly strong in pre-war collections. Books and reports were found using a keyword search; the data do not include journal articles.

From this figure, the beginnings of an increasing trend in publications can be seen in the early 1920s, and the trend continues until the end of World War II in 1945. A small peak is evident in the late 1950s and a large peak in the early 1970s. Since the mid-1980s, there has been a consistent increase until the present time. What types of social, political, and economic contexts brought about these 
Fig. 1 The number of resourcerelated works published in Japan since the 1920s.

(Source: University of Tokyo

Library database)
Trends of "Resource"related Publications

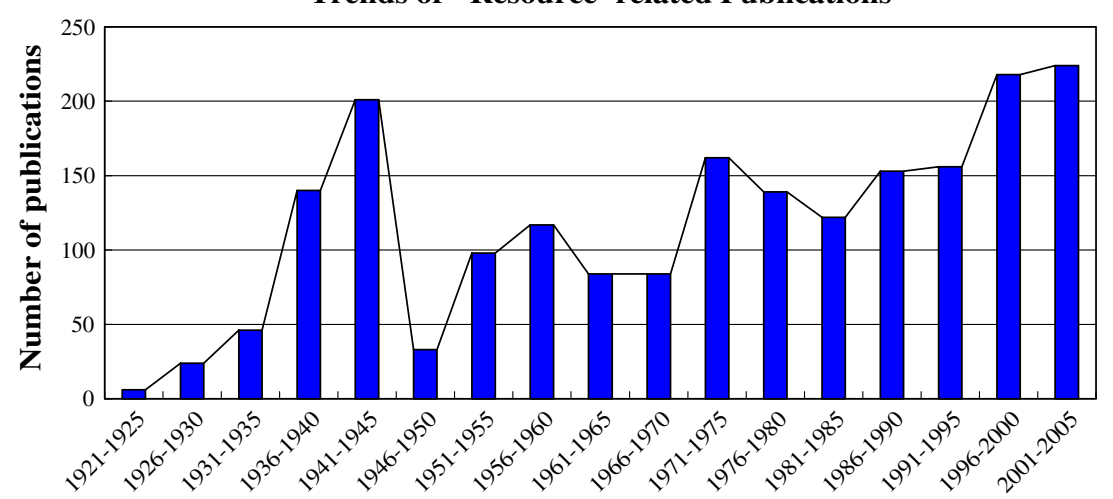

changes in each period? What kind of qualitative trends can be seen over these years? These questions will provide a starting point for the examination of the concept of "resources".

Resource-related publications of the 1920s primarily focused on Russia, Chinese Manchuria, and the Japanese prefecture of Hokkaido, where many untapped resources were identified for potential exploitation. Most of these studies were carried out by military or military-related research institutes, for example the Research Bureau of the Southern Manchurian Railways Company. From the 1930s on, the scope of the publications expanded to include Southeast Asia and the Pacific region (collectively known as nanyo) as realistic targets for supplying raw materials.

The sharp decline in the number of publications from 1946 to 1950 is not a reflection of a decline in public interest but of a general decline in the publishing industry as a whole due to war damages. As we shall see later, "people-oriented" resource policies were in fact a topic of intense debate in the Japanese government under the supervision of the General Headquarters (GHQ) of the Supreme Commander of Allied Powers (SCAP) until 1952. During the first post-war peak in the 1950s, resource-related publication topics focused on economic recovery, food supply, and flood prevention. A second peak occurred in the 1970s, when Japan had already joined the ranks of the global economic powers, reflecting a national interest in energy supplies, which then expanded into the global environmental movement in the latter half of the 1980s. Key concepts of the 1980s were "environmental conservation", "resource management", and "human resources", demonstrating the gradual expansion of the ideas covered by the resource concept.

Since the 1980s, there has been a consistent increase in public awareness in Japan of resource-related issues. The reason behind this growing attention is not necessarily an interest in resources per se, but concern over environmental issues, particularly those related to recycling and waste management. Additionally, "soft" elements such as information and national image are increasingly regarded as a resource by the Japanese government (Resource Research Council 1998). More recently, resource-related conflicts in the South China Sea and aggressive resource diplomacy by China have also helped attract public attention to this topic.

There have also been periodic efforts to systematize knowledge related to resources as an applied academic field. Although new fields, for example "national raw material science" (Tanaka 1928), "resource administration" (Sakata 1954), and "international resource studies" (Fukami 1972) have been proposed in the past, these periodic increases in interest were sporadic and never became a successful, coordinated movement. As expected, the most intense debates on resources in Japan seem to occur during periods of severe resource shortages.

\section{Dictionary definitions}

As indicated earlier, the resource concept in Japan is relatively new, and was first introduced around $1915 .{ }^{4} \mathrm{Al}-$ though it is difficult to identify the exact origin of the term, the process of its diffusion into public awareness can be traced through its appearance in dictionaries. In JapaneseJapanese dictionaries, the earliest appearance of the term shigen is in $1934 .^{5}$

For Western-language-to-Japanese dictionaries, a survey of 45 major French-Japanese, German-Japanese, and English-Japanese dictionaries published from 1867 to

\footnotetext{
${ }^{4}$ Before 1915, terms such as "raw materials" or "natural wealth" were used; however, these terms placed emphasis on material aspects and did not capture the nuances conveyed by "resource".

5 The author referenced eight major dictionaries, including 『言海 (Genkai)』(1891), 『辞林 (Jirin) (1907),『ことばの泉 (Kotoba no Izumi) (1908), 『言泉：日本大辭典 (Gensen: Nihon Daijiten) (1922), 『日本大辞典改修言泉 (Nihon Daijiten Kaishu Gensen) (1928), 『大日本国語辞典 (Dainihon Kokugo Jiten) (1915), and 『大言海 (Daigenkai) (1st edition 1915, 2nd edition 1933); none contained the term shigen (resource).
} 
Table 1 First appearance of shigen ("resource"): dictionary comparison

\begin{tabular}{lllll}
\hline $\begin{array}{l}\text { Dictionary } \\
\text { type }\end{array}$ & $\begin{array}{l}\text { Japanese- } \\
\text { Japanese }\end{array}$ & $\begin{array}{l}\text { German- } \\
\text { Japanese }\end{array}$ & $\begin{array}{l}\text { French- } \\
\text { Japanese }\end{array}$ & $\begin{array}{l}\text { English- } \\
\text { Japanese }\end{array}$ \\
\hline Year & 1934 & 1927 & 1931 & 1915 \\
\hline
\end{tabular}

Source: Author's survey

$1958^{6}$ reveals that "resource" was first translated as shigen in 1915 in an English-Japanese dictionary, after which it gradually spread to other language dictionaries, as shown in Table 1.

The above table also indicates that the term was introduced in foreign-language dictionaries more quickly than in Japanese dictionaries and encyclopedias.

According to the Oxford English Dictionary (OED), second edition, there are five main definitions of the term "resource":

1a. a means of supplying some want or deficiency; a stock or reserve upon which one can draw when necessary;

1b. (pl.) the collective means possessed by any country for its own support or defense;

2. possibility of aid or assistance;

3. an action or procedure to which one may have recourse in a difficulty or emergency; an expedient, device, shift;

4. a means of relaxation or amusement;

5. capability in adapting means to ends, or in meeting difficulties.

Most dictionaries in Japan published before 1930 listed definitions included in the OED. However, there was no appropriate term to indicate a "collective means possessed by any country for its own support or defense" $(O E D, 1 \mathrm{~b}$.).

\section{Rise of the resource idea and "finite resources"}

Two major developments gave the resource concept in Japan new importance:

1. a military and bureaucratic need for a generic concept to describe the means to be mobilized for the purposes of national planning; and

2. the development of the conservation concept from an ecological perspective.

These developments were commonly derived from an increasing awareness of the finiteness of resources.

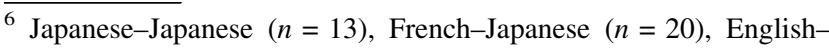
Japanese $(n=14)$ and German-Japanese $(n=12)$. A complete list of dictionaries can be found in Sato 2007 (unpublished).
}

The "mobilization" context

One source of the development of the resource concept was the planning section of the Japanese army that closely observed the development of World War I in Europe. These military observers concluded that a crucial aspect of modern war was not only combat capacity at the front lines, but also the supply of raw materials to back them up. The army started to use the term shigen towards the end of World War I (ca 1918) to emphasize the material basis for conducting a modern "sustainable" war. The first book that used shigen in its title was Resources for Imperial National Defense (Teikoku Kokubo Shigen) by Kuniaki Koiso, an Army major and later Prime Minister of Japan (1944). In his diary, Koiso states that his concept of "resources" was mainly influenced by the actions of Germany and other Western nations in developing a centralized system of raw material supply and distribution for war. ${ }^{7}$ The Japanese military was equally keen on following this trend to reevaluate the possibility of drawing on human and nonhuman potential in the private sector for combat purposes.

This awareness resulted in a push for nationwide research on the capacities of private factories that produced potentially useful goods for supporting the military. In addition, it led to the establishment of laws like the Resource Research Law (Shigen Chosa Ho) of 1929, which permitted the government confiscation of goods and productive facilities in the event of a national emergency.

The term fugen, literally translated as "natural wealth", was often used before World War I to describe the untapped profit potential of the natural world. Shigen, the present translation for the term "resource", was introduced to indicate a wider array of means, including the military power and economic strength of a nation, than merely the profit that is extracted from natural sources. Although shigen began to appear often in army magazines and publications around the early 1920s, the use of the term was still relatively limited and was often used interchangeably with fugen.

The dramatic spread of the resource concept with a clear direction for its meaning had to wait until a government official, Haruo Matsui, ${ }^{8}$ who played major role in creating the Resource Bureau (Shigenkyoku) in 1927 as a key plan-

\footnotetext{
${ }^{7}$ Koiso's diary, Katsuzan Koso, was published in 1963; a chapter titled "Resources for National Defense" (Kokubo Shigen) refers to his younger brother who told him about German material on wartime autarky ca 1916.

${ }^{8}$ Haruo Matsui (1891-1966) started out as a staff member of the Cabinet Legislation Bureau, which was then regarded as an elite branch of the Japanese government. He soon became director of the Planning and General Affairs Departments of the Resource Bureau, and was promoted to Secretary General of the Bureau in 1936. He also served as the governor of metropolitan Tokyo immediately after World War II.
} 
ning agency housed in the Cabinet Office. Matsui was greatly inspired by the leadership of US President Theodore Roosevelt in conservation and conservation-related movements, and widely publicized the resource concept in Japan.

It is important to understand why Matsui, a pioneering resource policy specialist, was attracted to the resource concept. He recalls his first encounter with the idea back in the early 1910s in an article on Roosevelt's conservation policy in The London Times. In his book Resource Policy (Shigen Seisaku) (Matsui 1938), which outlined his main argument why resource policy is essential, he argues that the most pressing issue of his time is "differentiation". By this he meant fragmentation and lack of coordination, particularly among government agencies that had expanded enormously and were following overlapping mandates. Matsui viewed "resources" as a unifying concept that provided an integrative perspective on various aspects, both human and material, of military strength. "Resources" was a particularly suitable concept for Japan, because it emphasized the development of potential materials, rather than the raw materials that were perceived as physically "scarce". Matsui instead placed high hopes on "human" resources and emphasized the importance of science, technology, and human ingenuity in filling the materials gap of the nation. In an interview, he recalls how he envisaged the resource concept:

Around 1923 or so, I read Richard Ely's small book which summarized what resource policy is all about ... Theodore Roosevelt was the one who translated this kind of idea into action. I found this movement quite interesting and told this story to the then chief of the Cabinet Legislation Bureau, Mr Yamagata ... to initiate a resource conservation movement in Japan. (Matsui 1975, p. 35; author's translation)

Matsui also introduced the idea of hoiku (nurturing) as his own translation for the English term "conservation", stating that "in a resource-rich country like the US, sustaining what they already have through conservation may be enough, but in Japan, which is a country with poor natural resources, there is a need for some element of resource development in addition to conservation. This is why I prefer to use the term hoiku". (Matsui 1975, p. 36; author's translation) Unfortunately, his idea was skewed towards military objectives and was thus overshadowed by the general mobilization movement that began in the 1930s and eventually led the nation into World War II. ${ }^{9}$ It is

\footnotetext{
${ }^{9}$ One of the standard explanations of the causes of the war was Japan's need for natural resources. However, Yasukichi Yasuba provides evidence that the "lack" of resources and the need for external acquisition of these materials were probably fictions created by the military as reasons to invade China and Southeast Asia (Yasuba 1996).
}

important to note that Matsui's main interest was in comprehensive national planning to integrate both the natural environment and human capacities, not the conservation of natural resources itself. A different line of investigation is therefore required to fully identify aspects of the resource concept that stem from an interest in conservation.

The conservation context

As Japan endeavored to reach the level of modernization of Europe and the United States, the government predictably placed a heavy emphasis on short-term production rather than long-term conservation of the nation's natural assets. However, a failure to influence government policy did not mean there was a general denial of the significance of the conservation concept. The preservation of the natural "landscape" became an issue addressed by private individuals and scholars instead of policymakers (see footnote 10).

This alternative way of thinking came to fruition in around 1919 with scholars and commentators observing the rapid degradation of the rural Japanese landscape, an inevitable side-effect of modern infrastructure development. The "preservation of resources" first became a topic of discussion in the House of Peers in 1919, when members Takio Izawa and Kyoshiro Inoue questioned Prime Minister Kei Hara on national policy towards the preservation of resources (House of Peers 1982, p. 71).

Izawa: I wish to ask about the conservation of natural resources ... Based on my experience as an officer in the countryside ... building a road, for example ... is a wonderful thing in and of itself ... However, if you look at the consequences, building many roads in the mountains will result in the deforestation of precious trees. That may result in the degradation of paddy fields. In a country like ours, where land area is limited, conservation of natural resources is something very important. (author's translation, emphasis added)

Izawa was not only talking about trees; by introducing the generic term "resources" he was referring to the foundation of economic development in general.

This was in fact the first occasion that the term "resources" appeared in a national policy discussion in Japan; Hara responded by denying the need to introduce conservation measures, arguing that human ingenuity can find technical alternatives even when certain resources are physically exhausted. As we can see, the deep philosophical divide between techno-centric optimists and eco-centric pessimists that persists today has its origin far back in history.

In addition to the ideas originating from Izawa's own experience in rural Japan, there was an effort to introduce the conservation concept more explicitly from abroad. 
Kiyoshi Sasagawa played an important role in this regard by introducing the idea of conservation to the general Japanese public through his 1917 translation of Charles Van Hise's landmark work The Conservation of Natural Resources in the United States (1910). In this book, Van Hise classified natural resources into four categories: soil, water, forest, and mineral. Although its content focused on the situation in the US, The Conservation of Natural Resources was probably one of the first comprehensive works on conservation made available to the Japanese public. In the translator's introduction to the book, Sasagawa also added an interesting comment that should not be overlooked:

In the same way that we feel a sixth sense outside of the realm of five senses, there seems to be a fifth endowment of nature that we must appreciate. This is my subjective and modest thinking, but this fifth asset seems to arise from a combination of soil, forest and water. We may call this fuko (scenic beauty). (Sasagawa 1917, p. 6; author's translation)

Sasagawa's contribution to the resource concept was not limited to his introduction of the conservation idea to the general public through his translation work. Although it only gained widespread public attention 50 years later, he described a concept (fuko) that was very close to the modern idea of "the environment".

Sasagawa's ideas on conservation seem to have appeared too early to enter the mainstream of policy debate. The concept and appreciation of "landscape" and its connection with nationalism were apparent in the late nineteenth century, yet policy discussions on how to conserve this landscape were absent at the time. ${ }^{10}$ The dominant policy in the early twentieth century was still to discover, extract, and utilize resources for strengthening the military capacity of the nation. In sum, the resource concept was brought about by awareness of the "finiteness" and shortage of means, notions that were both attached to national, not local, interests. Although we find the seeds of interdisciplinary principles in the resource concept of these prewar policies, the full flowering of the idea had to wait until the end of World War II.

\section{The second wave and the democratic turn of the 1950s}

Establishment of the resource committee

The total defeat of Japan in 1945 brought new and pressing questions about resources. This time, however, the chal-

\footnotetext{
10 A ground-breaking book on landscape was Shigetaka Shiga's Treatise on Japanese Landscape (Nihon Fukeiron), published in 1894. This book is one example of the backlash against the Western influence on all aspects of Japanese society during the Meiji era.
}

lenge came from a completely different angle; instead of expanding national capacity, now the central policy question was how to feed a hungry population of 80 million. Until the end of the war, Japan had effectively portrayed itself as a member of the resource-poor, "have-not" nations, and this perceived shortage had justified the invasions of China and Southeast Asia. As the technical advisor to the Supreme Commander of Allied Powers, Dr Edward Ackerman, reflected after the war: ${ }^{11}$

One of the most repeated and most effective instruments used in the psychological warfare was the "have not" campaign conducted by the Fascist powers before and during the last war. Japan, like Germany, presented itself as a poor but deserving nation intent only upon getting enough to keep its growing population alive (Ackerman 1948, p. 32).

Post-war Japanese interest in resources started with the issue of food security. Starvation was a serious concern for the government, which feared massive anti-government movements resulting from food shortages. During this period the Economic Stabilization Bureau (later the Economic Planning Agency) was established primarily to address the food security issue and other areas of direct relevance to the livelihoods of people (i.e. energy, water, and land). It is ironic that the first institution to comprehensively address the resource situation in Japan was an American organization, the Natural Resources Section established within the General Headquarters (GHQ) of the Supreme Commander of Allied Powers that governed Japan until 1952.

Defeat in World War II and the subsequent establishment of the GHQ had a substantial impact on Japan's postwar resource ideas and policies. Ackerman, for example, introduced the idea of "integrated planning" to Japanese bureaucrats who were eager to learn democratic methods of resource governance. ${ }^{12}$ Ackerman also advised the creation of a governmental Resource Committee; this would play an important role in implementing the idea of "resources as one" as exemplified by the Tennessee Valley Authority

\footnotetext{
${ }^{11}$ Ackerman inspired many personal reminiscences despite his short residence in Japan. Saburo Ohkita, who later became the Minister of Foreign Affairs, wrote in his memoirs that he, along with other young bureaucrats, visited Ackerman's office almost every week to discuss resource problems (Ohkita 1949). Also recommended are the recollections of Tohru Ishimitsu, who served as Ackerman's research assistant during his time as a technical advisor to the GHQ (Ishimitsu 1999).

${ }^{12}$ In 1949, the Japanese translation of TVA: Democracy on the March (David Lilienthal) became available; a TVA study group within the government was also appointed to study the impact of this project. The actual application of principles that characterized the TVA was attempted in the Kumano water systems development plan covering Nara and Wakayama Prefectures.
} 
(TVA), which tried to integrate all dimensions of water, infrastructure, employment, and electricity supply into a unified policy.

From 1950, the Korean War unexpectedly boosted the Japanese economy, and the country gradually regained its industrial capacity; with this development came a second wave of interest in natural resources. Consequently, following the recovery of economic capacity and the end of the US occupation, publications and studies addressed the future vision of the nation, and grand designs for development became the focus of discussion during this period.

In reviewing the shorthand minutes available from meetings of the Resource Committee since 1951, it is not difficult to detect the complete absence of "democracy", the central concept infused into all aspects of post-war governance in Japan, in resource-related policymaking. Two factors in the establishment of the Resource Committee may explain this absence. First, Ackerman did not want Japan to suffer from the political struggles over control of the direction of resource policy that had plagued the US, where the original mission of the committee to provide technical expertise was lost amid political manipulation. Therefore the Japanese version of the Resource Committee deliberately limited its mission to purely technical and scientific concerns (Ohkita 1949). Second, the need to clarify its bureaucratic turf was also a factor, as ministries and committees related to national planning already existed. To justify its existence, the Resource Committee had to carefully limit its mandate to scientific research and technical advice on cross-ministerial issues.

Appeals to science and technology, or the study of "things", are inherently accompanied by the risk of compartmentalization of work according to the technology available in the respective disciplines. Thus, the performance of the Resource Committee must be evaluated in terms of the exact manner in which an integrated approach to resource governance was achieved. Upon its initiation in 1947 the Committee started out with four technical subcommittees on water, land, energy, and minerals. These areas were selected on the basis of the urgency of the problems faced by the general population in various locations across Japan.

The Resource Committee soon developed into the $\mathrm{Re}$ source Research Council (Shigen Chosa Kai) in 1949, which became, intriguingly, the leading center for a holistic approach to resource management. An example of this approach was the inclusion of pollution and degraded resources in the committee's mandated research targets. At the time Japan was unable to afford the luxury of increasing the productive capacity of its available resources, let alone account for sources of negative productivity, for example degraded rice fields or malfunctioning reservoirs and canals. By including these negative aspects into its research agenda, the Resource Research Council was able to integrate disaster research and resource policy into a unified planning target field. ${ }^{13}$

This ideal method of integrated planning was initiated when the Resource Committee created the Regional Planning Subcommittee (Chiiki Keikaku Bukai) in October 1948. This subcommittee was responsible for the actual application in the field of the policies and decisions generated by more technical subcommittees. The decisions surrounding the creation of this group are also of interest. According to the minutes of a meeting held on May 10, 1948, Shunichi Uchida, the Committee Chairman, raised this question: "If we leave the subcommittees as they are, they will go in each direction without any coordination. How can we coordinate them towards a common objective?" Ukichiro Nakaya, a committee member, then suggested: "Let us target the region and problems first and then organize water, energy, and land issues surrounding those problems." (Regional Planning Subcommittee of the Resource Research Council 1952, p. 3; author's translation). Thus, the Resource Committee attempted to situate a major organizing force in the field to act as a centralizing force for knowledge integration.

\section{The forces of integration}

Except for the first few years of the post-war era, when "human" was deliberately excluded from the definition of resources, there has been a general trend of expansion of the resource concept in Japan. Particularly after the 1980s, the resource concept expanded to include "soft" dimensions, for example the ability to utilize information or influence other countries through cultural-political means (Resource Research Council 1998). However, a rapid comeback of traditional ministries wanting to defend their own turfs overshadowed the rold of cross-ministerial Resource Council, and the unifying force of the resource concept faded away.

What are the lessons that emerge from this half-century of resource policy debate in Japan? As shown in this paper, the orientation of resource policy was drastically different before and after World War II. In the pre-war period the military government used the resource concept to create a comprehensive inventory of the nation's military forces, and "resource" was thus a convenient term to neutralize

\footnotetext{
13 The Resource Research Council still exists, although greatly diminished in size and scope. In 1956, the Resource Bureau, which served as a secretariat to the Council, became the core of the Economic Stabilization Board (Keizai Antei Honbu) in the newly established Science and Technology Agency. In 2001, it was further downgraded to the Resource Section of the Ministry of Education, Science and Sports.
} 
the aggressive connotations of top-down military mobilization. After the radical turn to democratic principles in 1945, "resource" was suddenly assigned a symbolic meaning as a means to serve the people. Despite these radical contrasts, however, pre and post-war resource concepts share a commonality in the sense that the government acted as the centralizing force, providing a platform to integrate disparate knowledge (e.g. on materials, conservation, labor, information) under the resource concept. For various reasons, the integrative effect of the resource concept was the result of necessity rather than academic endeavor or the idealistic pursuite of holistic approach.

As Japan is now wealthy enough to import the various resources it requires, it is appropriate to ask whether the resource concept can be relevant or revitalized in the present context of the globalized economy. The creation of the Resource Committee during the post-war period may provide some hints on this process. The original function of the Resource Committee was not necessarily to develop an integrated field of resource science as such, but to serve instead as a barometer of various resource problems. In other words, the committee functioned as a mechanism to help prioritize issues and to concentrate technological advancement in the areas that were in the greatest need of development from a cross-sector perspective.

In the second edition of the Oxford English Dictionary "resource" is defined as "a stock or reserve upon which one can draw when necessary". The phrase "when necessary" seems to imply that there are times when certain resources are perceived as unnecessary and thus are dismissed. In modern society, goods and services produced for direct human utility are now mainly provided by the state and the market. As the international market has emerged as the key distributive mechanism for desired goods and services, the management of resources that do not produce immediate utility, but instead indirectly serve as an economic foundation, requires systematic and long-term attention; we never know what will become necessary, or when.

Because of the continuing compartmentalization of knowledge, however, analysis of resources has usually meant a study of individual raw materials, for example soil or water. Consequently, despite the expansion of knowledge about the material aspects of resources, such analyses provide little in the way of policy advice on how to use, share, and redistribute resources wisely within a society. Studies of individual materials do not lead to insights into how priorities can be set in policy choices. At a time when society itself is more prone to fragmentation, the resource concept that played a significant role towards unification in the past should be re-examined. The history of the resource concept in Japan, particularly during the pre and post-war period until the 1950 s, contains a wealth of insights into how this can be achieved. As the world faces the urgent problem of balancing economic development and environmental conservation, the revitalization of the resource concept to facilitate integration of the two realms could not be more timely.

\section{References}

Ackerman E (1948) Japanese Resources and United States Policy. In: A Key to Japan's Recovery: natural resources policy and the occupation. Japan Resources Association, Tokyo 1985

Fernow BE (1896) Providential functions of government with special reference to natural resources. In: Proceedings of the American association for the advancement of science, August-September 1895

Fukami H (1972) Resource problems in international economics: an attempt to establish international resource studies (in Japanese). Mita Gakkaishi 63(12):17-24

House of Peers (1982) Shorthand notes of the 42nd imperial parliament meeting (in Japanese). University of Tokyo Press, Tokyo

Ishimitsu T (1999) Dr. Edward Ackerman and japanese resource policy (in Japanese). Geography 44(6):48-57

Japan Resources Association (ed) (1985) A key to Japan's recovery: natural resources policy and the occupation. Japan Resources Association, Tokyo

Matsui H (1938) Japanese resource policy (in Japanese). Chikura Shobo, Tokyo

Matsui H (1975) Round table discussion record: from Resource Bureau to Central Planning Agency. In: Commerce and Industry Administration Record (in Japanese). Institute of Industrial Policy History, Tokyo

Ohkita S (1949) Resource problems of Japan: footsteps of Dr. Ackerman. In: Japan Resources Association (ed) Technology, Resources and Economy. Hakuyousha, 1985, pp 311-320

Regional Planning Subcommittee (1952) Background to the establishment of the regional planning subcommittee and its research activity (in Japanese)(mimeo) (No.226). Resource Research Council

Resource Research Council (1998) Future of resources: research report on Japanese resources in the 21st century. Resource Research Council, Science and Technology Agency, Tokyo

Sakata Z (1954) Resource studies and resource administration (in Japanese). Shigen 49

Sasagawa K (1917) Fugen Hozonron (Theory of resource conservation). Translation of Van Hise C (1910) The conservation of natural resources in the United States

Sato J (2007) Historical formation of the resource concept in Japan (in Japanese). Mimeo

Tanaka S (1928) Theory of raw materials in Japan (in Japanese). Association for Japanese Raw Materials Policy, Tokyo

Yasuba Y (1996) Resources in Japanese economic history: from 1800 to 1940 (in Japanese). Socio-Econ Hist 62(3):291-312 